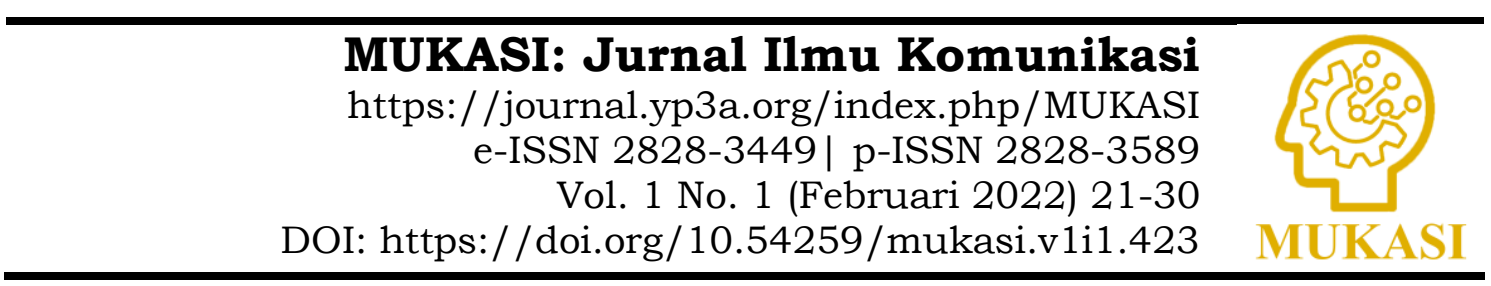

\title{
Bridging Digital Communication Amongst Digital Natives
}

\author{
Yakobus Suharyono \\ Program Studi Ilmu Komunikasi, STIKS Tarakanita Jakarta, Indonesia \\ suharyono.yakobus@gmail.com
}

\begin{abstract}
Distance learning becomes critical alternative in educational practices. Digital technology is becoming an opportunity. Don Tapscott's net-gen proposes the upcoming phenomenon of the digital-natives which are somewhat different from those of digitalimmigrants. This research observed digitally distance educational learning teaching activity occured amongst digital-natives conduted by using GoogleMeet, GoogleClassroom, WhatsApp platform and YouTube.com Channel. It aims to portray how distance learning activity was implemented amongst the elementary students in the era of covid-19 pandemic in Bekasi. The observation was done by joining into social media group of students and teachers. The result shows that both interpersonal perspectives and educational philosophical aspects must be put together sinergically into distance class on the basis of technological competences and literacy in educational environment on which the value of social compassions amongst learners must be encouraged too. When they are sinergically melted in the process of learning communication and relations, the optimal academic performance was possibly gained.
\end{abstract}

Keywords: Distance Learning, Digital Natives, Interpersonal Communication, Educational Philosophy, Technological Competence and Literacy.

\section{INTRODUCTION}

Digital natives or Net Generation are broadly understood as Digital Generation. It is

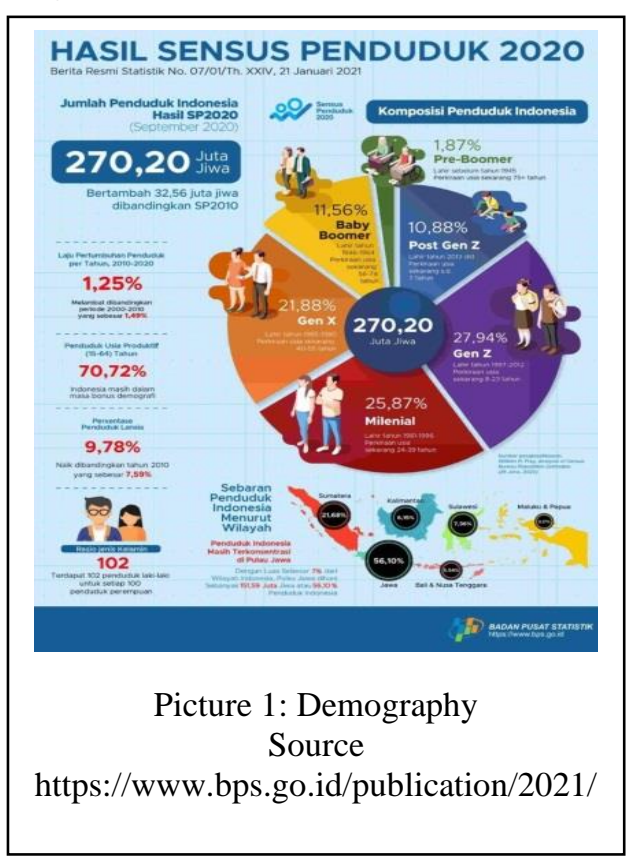
characterized by the norms of freedom, customization, scrutiny, integrity, collaboration, entertainment, speed, and innovation. (Tapscott 2008: 74-96) Those characteristics are somewhat possibly to be generated into three broad categories of having digital and media literacy, having eagerness to apply other approaches in their learning activities more than the older generation, and having sense of the technological savvy.

Indonesian Demography states that the baby boomers generation covers $11,56 \%$ of the population; Gen X covers $21,88 \%$, making total of $33,44 \%$. The millennial $(25,87 \%)$, Gen $Z$ $(27,99 \%)$ and Post Gen Z (10,88\%) contributes $64,74 \%$ of the population. This research focuses on the Gen Z's learning activities. This generation was commonly born between 1997 
until 2012. They are now on the age of 8 until 23 years. (https://www.bps.go.id/publication/2021/) To be more specific, the subject of this research are those generation in the $5^{\text {th }}$ and $6^{\text {th }}$ class of elementary school.

Due to widely-spreaded Covid-19 pandemic, the Minister of Education instructs all educational institution in all level to conduct their educational teaching learning activities digitally. Besides, the government also instructs most of the office to be managed and operated form home digitally. The regulations of work from home (WFH) and learn from home (LFH) are wildly applied in all provinces. UNICEF also encourages worldly this LFH strategy. (www.unicef.org, accessed 1 Feb 2021)

Cultural, digital and socially shocks occur. Either mostly teachers or students are generally not ready for the extreme change caused by this pandemic. Culturally, teachers are mostly comfortable with face-to-face interaction during the learning teaching process. Education philosophical ideals such as the ethics and norms transfer and the unavailability of the learners' readiness are usually the basic issue to defend older generation from the rapid change nowadays. Digitally, many are still illiterate in the technological development and telecommunication convergences. The issue of media and digital literacy is still on a theoretical basis. Different from this condition, Gen $\mathrm{Z}$ is characterized by their inability to be separated from digital devices. They are more fluent in digital surfing much more than the older generation. They are technological savvy. Socially, digital disruption amongst the generation is still critical. The internet accessibility varies from place to place. Those living in cities may find and connect to the internet network, but those in rural areas still face problem due to the internet network accessibility.

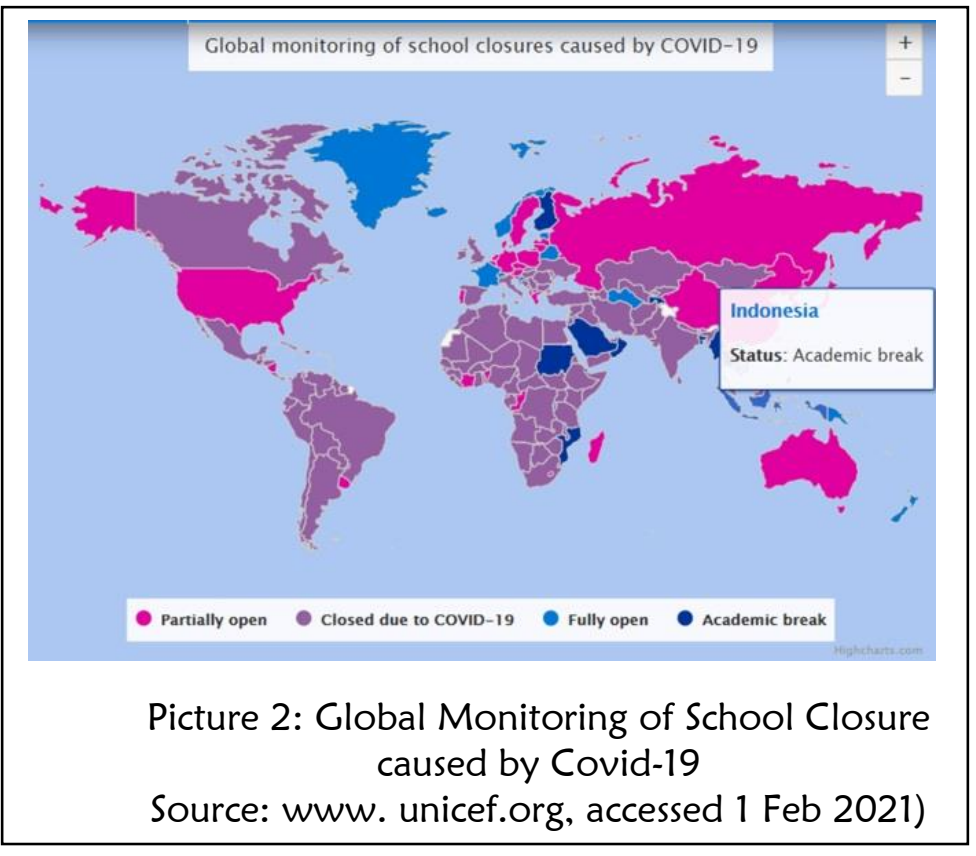

On the other hand some researchers that this pandemic-influenced

situation also creates problems as well as prospective opportunity and challenges in the field of education. Joko Suprapmanto and Utomo from Nusa Putra University finds that the ongoing situation creates problems in learning teaching process. It dues to the cultural shock of having to face and deal with digital culture of learning teaching activity. Arjunina Maqbulin

from MAN 2 Nganjuk East Java and Yustinus Budi Hermanto sees the pandemic as either an opportunity or challenges. (Maqbulin 2021; Hermanto 2021; Safrizal 2021) In this article approaches will be highlighted based on the concept proposed by Prensky's theory of digital natives and immigrants. The concept will be reviewed based on the local philosophical Driyarkara's educational wisdoms. It is intended to portray the ideal digital learning under which the sinergy of interpersonal communication, educational philosophy and technological competence conducted in a melting process of online learning help learners gain optimal academic performance. 
The research is outght to be beneficiary in some points. Amongst this pandemic, digital learning must be academically beneficial for learners and teachers as well as fcae-to-face learning. For the sake of this consideration some points to ponder can be generated such as interpersonal competence of communication, the understanding of educational philosophy and technological literacy of teachers. Teachers should acquire those three.

\section{THEORETICAL REVIEW}

Distance Learning

Distance learning is the process of learning teaching activities when both students and teachers are in separated places. The process then is conducted by using the help of internet, e-mails, virtual communication or video conference. This method of learning does not require students and teachers to have face to face interactions. (Merriam Webster Dictionary) Different from distance learning, online learning includes the use of online tools and platform as if it is in regular classrooms. Besides, teachers and students can still communicate each other virtually. Online learning can be somewhat a supplement for other form of learning methods. (https://uopeople.edu)

Distance learning seems to be a mandatory even though there are some issues that, after years of the pandemic, is still unable to be completely solved. The first reason is the digital disruption amongst students in all parts of the country. The mountainous archipelago of Indonesia proposes distinctive landscapes that it is almost an imaginary to have one single platform for the digital communication processes. The second, seems to be the most critical, is the unprepared capability of most teachers to settle the ideal technology-based learning process in digital learning media. This results in many manifestation of dis-teaching behavior characterized by the implementation of learning teaching activity as just 'store and get' phenomenon, one fit for all behaviors assesments, boring and stressful learning process and imbalance digital literacy. The issue of the missing social-contexts and big challenges in assessment make the educational problem become more complicated. (Sahid 2020)

\section{Digital Natives}

Students nowadays are different greatly from those of the previous eras. The education system in the previous time is somewhat no longer applicable. What teachers have designed in many cases does not meet their needs due to their characteristics as people who live in this digital era. This generation has changed revolutionarily especially since the arrival and broad development of digital technology in the $20^{\text {th }}$ century.

Don Tapscott, in his book entitled 'Grown Up Digital' 2008, elaborates deeply about the phenomena of what so called as the Internet Generation (Net-Gen). The characteristics of this net-gen is broadly known as, Prensky says, digital natives. This also what so called 'news students' is considered to be digital natives. "Our students today are all "native speakers" of the digital language of computers, video games and the Internet" (Prensky 2001:1) For further discussion, Tapscott explains 8 norms possessed by this net generation that in many ways, the digital immigrants do not. Born and grown to be free agent (freedom), customization specified, speed-operating person are parts of their lives. They are also considered as people who possess the norms of scrutiny and integrity. They tend to be proactively collaborative individuals. They pay attention a lot on entertainment. They seek innovation, frequently getting bored with the oldies - ideas, routines, etc. (Tapscott 2008: 73-96)

To be different from digital natives, older generation is to be specifically said as digital immigrants, since they are still trying to adapt to their new environments but their 'accent' is unluckily still in the past. This older generation usually deals with manuals 
when entering into new devices or system, while the natives tend to be 'just do it', just like propaganda of an internationally-produced shoe. This always ask people to come physically to see our web while natives send it in the form of Uniform Resource Locators (URL). This frequently asks students to define a terminology while natives cannot understand it. The immigrants always work in a serious-designed office, while natives prefers 'games' when working. Digital natives receive information very fast. Digital immigrants sit in class and on the library, while natives bring a bug of books, music, messages and any other documents on their pocket digital devices. They are multitasking: doing some different things seems inattentively, while the immigrants cannot. (Prensky: 2001)

Interpersonal Perspective of Communication

To some extent, interpersonal communication usually takes place in the classroom where teachers and students meet. They communicate and, it is wished greatly furthermore, relate. In normal environment this inetrpersonal communication occurs either in dyadic or in classical communication.

Refferring to interpersonal communication in classes we might intuitively access commmunication models. There are many of the models, some of them are possible relevant to the communication usually conducted in class where teachers and students are in together enggagement.

Commonly understood, the most frequently used communication model in classes might be the Theodore M Newcomb's ABX communication model. This model of

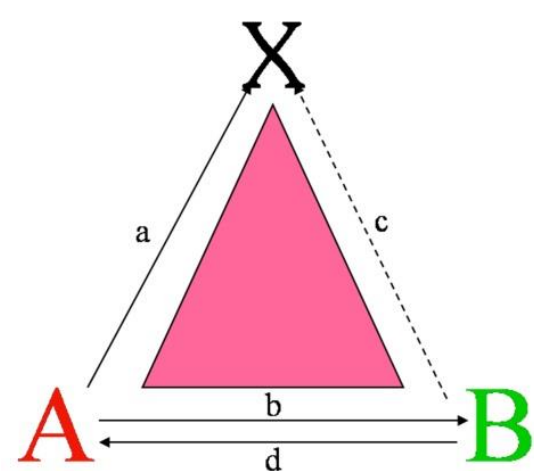
communication encourages the role of the communication as a medium of social relational enggament. Besides it maintains social equillibrium in a social system such as students in classes. The relationship occuring in classes are between teacher (A) and student (B). They are communicating at the same flow. "X" shows something being the center of the communication or discussion. When teacher is explaining learning material of certebrata and invertebrata, the communication diagram becomes:

\begin{tabular}{ccc}
$\begin{array}{c}\text { A - } \\
\text { Teacher }\end{array}$ & B - Students & $\begin{array}{c}\mathrm{X}-\text { issue / topic of } \\
\text { vertebrata \& invertebrata }\end{array}$ \\
\hline
\end{tabular}

The equillibrium of understanding between both teacher and students on the topic or issue of vertebrata and invertebrata shows that the communication between them works well. Otherwise it might be a problem in their social system of interaction. http://communicationtheory.org/

The second most frequently used communication model might be the Harold Dwight Lasswell's Communication Model.

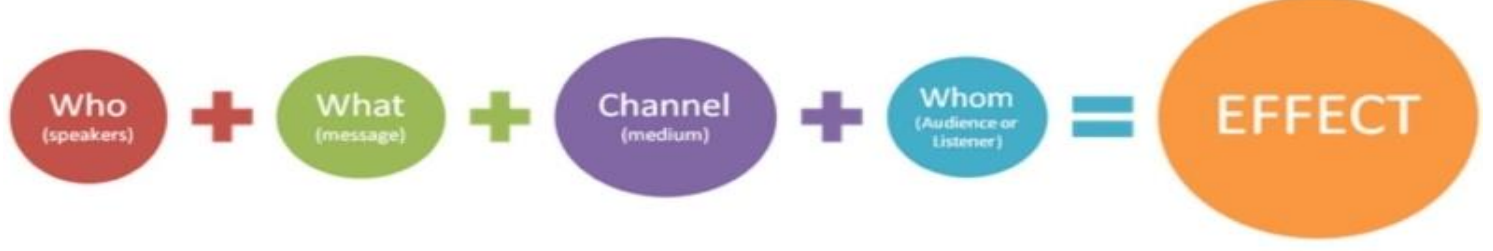

This communication model seems to suit almost all types of communication. It proposes a cultural transmission between generations (teacher and students) as well as dealing 
with the concept of effect of the communication itself in a multicultural society with heteregenous audiences (students). Ideally in class, teacher transfers knowledge and norms to students via various learning teaching channels which in turns expect the students to acquire sets of learning material understanding, skills and applying intended norms. http://communicationtheory.org/

The two models of communication as stated above usually apply in the normal face-toface interpersonal communication in class. This, due to the pandemic, moves slightly into virtual. Since digital learning becomes critical alternative in learning teaching process nowadays, this communication process should be done by online. This shows that interpersonal communication can take place in varied forms either face to face in a classroom or in distance. The basic principles are that the interpersonal must be conducted in the spirit and norm of being relational. This relational interpersonal communication must involve interdependent individuals. This is possible when students are all 'connected' as if they are father and son or daughter which is feeling free to express ideas. In other word, establishing and developing a dyadic communication is the most welcome to happen. (De Vito 2016: 26-29)

\section{Education Philosophical Norms}

Education is conceptually understood as the fundamental process of humanizing young generation which is conducted attentively. This is characterized by some paradigms, such as (a) young generation shows that education must be addressed to the generation since in the beginning of ages. (b) attentively-conducted process shows that education is operated under design based on the educational goals by implementing the standardized strategies. (c) Education encourages sharing the norms of homo homini socius, not homo homini lupus. (d) Education is family-friendly oriented to enhance social and cultural diversity. Driyarkara says that education must be hominization and humanization oriented. (UU No. 23 Th. 2003, Driyarkara 2006: 366-376; Webinar Strada)

Hominization theoretically reviews about the process of being human as general. Every single human being is human. It is not a single animal. He is person or subject who always tries to understand what kind of person he is. He tries to decide to be what kind of person he shall be. He knows what to do. He is responsible for what he has been doing.

Humanization is represented on human's behavior and attitude to move forward to be better amongst his social and cultural environments. To show an example, after drinking a bottle of plain water, a young boy throws the bottle away disrespectfully. During the process of education, the young boy is encouraged to throw the bottle by putting it into a trash bin. Realizing that putting a bottle into the bin after using it is showing a level of humanization of an education process by which the young generation is trained to have a higher level of norms compared to the ordinary people. (Driyarkara 2006: 368-369)

\section{METHODS}

Observation method is applied in this research. After being permitted by the class teachers, the researcher joint into the Whatsapp group of the classes. The observation is done by examining every chat amongst the members of the Whatsapp group. Besides the researcher also follow the activities conducted by the teachers through GoogleMeet Video Conference, GoogleClassroom Assignment Submission Platform and Youtube.com channel. The observation starts from May 2019 until May 2021. The subjects of the observation are $5^{\text {th }}$ and $6^{\text {th }}$ grade students of Strada Budi Luhur 2 Elementary School Bekasi. Data are coded and then theme-based explained descriptively. 


\section{FINDINGS AND DISCUSSIONS}

After the observation on the learning teaching process to digital natives some important findings can be generated as follow:

1. Interpersonal Perspectives: Developing relation

As has been discussed in the previous part, interpersonal communicaton must be conducted in the spirit and norm of being relational. As one axiom in communication developed by Paul Watzlawick "one cannot not communite', showing that people start communicating immediately after they perceive each other. Every communication, to be claimed as communication itsefl, muast contain aspect of content and aspect of relationship. The content is the messages being communicated but the relationship determines the content in vice versa. One single content might possibly perceived differently because the relationship between communicator and communicant might change. (http://scihi.org/communicationpaul-watzlawick/; Webinar Strada) So, underlining the axiom, teacher must realize that one cannot not communicate, and one cannot not relate. These communication and relation process wetween teacher and students must be implemented either in a face-to-face learning or in distance learning activity.

This relational interpersonal communication must involve interdependent individuals. This is possible when students are all 'connected' as if they are father and son or daughter which is feeling free to express ideas. In other word, establishing and developing a dyadic communication is the most welcome to happen. (De Vito 2016: 26-29)

As usually occur in face-to-face class, dyadic communication, a two-way relational communication between teacher and students, is also found important during the distance learning. Distance learning is not merely a 'store and get' class. Not only storing learning material on the platform, teacher all of the time plays important role to encourage the process of dyadic relational communication to the students. This, in this distance learning, is mostly done by greeting the students in the morning before starting the online class and in the afternoon to say good bye and to inform the next learning plan. When teacher greets the students through WhatsApp group, the students always immediately reply by saying the similar expressions. As well as greetings, thanking is always communicated in every session when teacher is to close and dismiss the class. The most frequently used expressions are:

\begin{tabular}{|c|c|c|}
\hline $\begin{array}{c}\text { ORIGINAL } \\
\text { EXPRESSIONS }\end{array}$ & $\begin{array}{l}\text { EXPRESSIONS } \\
\text { IN ENGLISH }\end{array}$ & FREQUENCY \\
\hline $\begin{array}{l}\text { Selamat pagi anak anak } \\
\text { terkasih }\end{array}$ & $\begin{array}{l}\text { Good morning dear } \\
\text { students }\end{array}$ & Always on every session \\
\hline Terima kasih anak-anak & Thank you dear students & Always on every session \\
\hline Terima kasih Pak Guru & Thank you Mr..... & Always on every session \\
\hline Terima kasih Ibu Guru & Thank you Mrs. .... & Always on every session \\
\hline Berkah Dalem & May God bless you all & Always on every session \\
\hline $\begin{array}{l}\text { Anak-anak, Bapak Guru } \\
\text { ingatkan, anak-anak harus } \\
\text { selalu menjaga kesehatan. } \\
\text { Selalu cuci tangan. }\end{array}$ & $\begin{array}{l}\text { Dear students, I would } \\
\text { like to remind you to keep } \\
\text { yourself healthy. Wash } \\
\text { your hands frequently. }\end{array}$ & Always on every session \\
\hline $\begin{array}{l}\text { Anak-anak, apakah kalian } \\
\text { sudah mengerjakan PR? }\end{array}$ & $\begin{array}{l}\text { Have you finished doing } \\
\text { your homework, dear } \\
\text { students? }\end{array}$ & $\begin{array}{l}\text { Always (when teacher } \\
\text { gave home assignment the } \\
\text { day before) }\end{array}$ \\
\hline
\end{tabular}




\begin{tabular}{|c|c|c|}
\hline $\begin{array}{l}\text { Anak-anak, Pak Guru } \\
\text { minta tolong. Bantulah } \\
\text { teman-teman yang tidak } \\
\text { bisa mengakses pelajaran } \\
\text { sekarang. } \\
\text { fotokopy } \\
\text { pelajaranmu kepada yang } \\
\text { tidak bisa akses. }\end{array}$ & $\begin{array}{l}\text { Please help your } \\
\text { classmates who are unable } \\
\text { to access (to the zoom } \\
\text { meeting) Send your copy } \\
\text { of your notes to them. }\end{array}$ & $\begin{array}{l}\text { Always (when a student } \\
\text { send notification he / she } \\
\text { is left behind from the } \\
\text { zoom meeting and miss } \\
\text { the notes of the lesson }\end{array}$ \\
\hline $\begin{array}{l}\text { Pak Guru, si XXX sakit, } \\
\text { tidak masuk kelas }\end{array}$ & $\begin{array}{l}\text { s sick, unabling to } \\
\text { class }\end{array}$ & $\begin{array}{l}\text { Always (when a student is } \\
\text { sick) }\end{array}$ \\
\hline $\begin{array}{l}\text { Kita berdoa ya anak-anak, } \\
\text { untuk teman kalian yang } \\
\text { sakit. }\end{array}$ & $\begin{array}{l}\text { Let's pray for you friend, } \\
\text { dear students }\end{array}$ & $\begin{array}{l}\text { Always (shared by } \\
\text { classmate when a student } \\
\text { is sick) }\end{array}$ \\
\hline $\begin{array}{l}\text { Pak Guru, si YYY } \\
\text { listriknya mati, tidak bisa } \\
\text { zoom }\end{array}$ & $\begin{array}{l}\text { Mrs. ... YYY is unable to } \\
\text { join our class. The } \\
\text { electricity went out }\end{array}$ & $\begin{array}{lrr}\text { Always } & \text { (shared } & \text { by } \\
\text { classmate } & \text { when } \\
\text { happens) } & & \\
\end{array}$ \\
\hline
\end{tabular}

This form of communication shows and teaches the students about 'being respectful' to others, either to the teacher or to their peers. This is promoted by both classroom and subject teachers. By distance learning, communication amongst them is still being intensively developed. The relational enggagement is shown by the immediate responses from students. It continues to be maintained.

2. Educational Philosophy: Developing respectful habitus

Acquiring academic excellence is one of the mottos of this school. Dealing with it, teachers collaboratively design the content of teaching based on the standardized curriculum. Instead of delivering the learning materials in class, due to the pandemic, they upload them in to YouTube channel. The link is shared via WhatsApp Group. The learning teaching process is then conducted by using GoogleMeet platform. This is sometimes is combined by using GoogleClassroom whenever teachers ask students to submit certain assignments. Or, students are encouraged to access Youtube.com channel to learn other relevant learning materials. Cognitively, students' assessments are conducted in the form of either formative and summative test via Learning Management System (LMS)

Managing distance learning by using a sinergetic combination of digital platform such WhatsApp Group, GoogleMeet, GoogleClassroom, Youtube.com channel and Learning Management System collaboratively is managed in a such a way by school management in order to educate students the norms of unlimitable learning sources. Teacher is no longer the only source of knowledge and norms spokepersons. Students may get bugs of knowledges and norms models bu accessing lots of digital platforms.

It might be difficult to create and develop an educational-friendly habitus whenever the class is operated online. Many say that online is only appropriate for transferring theoretical knowledges. Educating soft skills is almost considered impossible. But, facilitated by the online class, teachers factually enthusiastically encourage students to learn the material and finish the assignments tactfully. Asking not to postpone what the students can do today, the teachers persuade them to deal with the material frequently and to submit their assignments on time. There are some students who are most of the time late in this assignments submission. Relating to this 'lazy' learners, the teachers are not reluctant to remind them 
through WhatsApp group chats. This results positively in peers collaboration in which they reminds each other dealing with their assignments submission. Those 'lazy students' then realizes that they are left behind in learning and assignments submission. When they ask for further information or help, others are mostly willing to help either by showing the further helpful instruction or guiding them to do the assignments until their assignments are completely done.

Social compassions come in reality, for example, when a student or two cannot join the google meet due to digital or network problem, others try to help give ways of how to rejoin or reconnect to the class. This is done via chat on WhatsApp group. Yet if he cannot join, they communicate digitally each other to discuss about what has been taught by the teacher. Furthermore, they report to the teacher about the problem; and teacher encourages them not to be upset. In several occasions, teacher asks the students to help each other by discussing the materials. The teachers offers their willingness to kindly repeat elaborating the material thoroughly in the next session.

Today's teachers must communicate on the same way the digital natives do. Teacher should make the content of the education go faster, reducing step-by-step boring procedures but presenting things to learn in a more random comprehensively multi-dimensional access. But on the other hand, educating what is important to the students is still a mandatory. In relation to this methodology, applying the method of reflective pedagogy paradigm as proposed and practiced by the Jesuit is considered relevant. (ICAJE)

Transferring teaching contents in such a way that attract students' willingness to finish the process as shown by their hard attempts to submit the assignment outstandingly without omitting the spirit of being collaborative amongst them is always in the process. This consists of two.

a. Legacy content. It includes most of all competences of our traditional curriculum such as reading, writing, arithmetic, logical thinking etc. All of them are important but some will be considered to becoming less.

b. Future content. It is a large extent of competences, and most of them are digital and technological. Prensky describes "It still includes the discussion of ethics, politics, sociology, languages and other things that go with them" (Prensky 2001) This is interesting for digital natives. They 'need to get prepared' to face it.

\section{Technological Competence and Literacy}

Conducting distance learning needs to acquire technological competence. As a matter of fact some teachers are of digital immigrant. They are not really capable of the digital devices operation. To be capable of handling digital devices the teachers are accompanied and encouraged by the management of the school. Teachers are conditioned to collaborate to produce teaching contents. These contents are posted in their learning teaching digital platforms. Respectfully, the students are in turn encouraged to develop either their knowledge or technological competences and literacy by moving around from one digital learning platform to the other.

Duderstadt (2004) as cited by Sharon Stoerger proposes an immediate change to education and technology. The upcoming development of technology should, not in narrow-minded perspective, be considered as a futuristic opportunity and challenge by which teacher shall be able to take part in education process towards 
the digital natives, making them competent as well as socially improved. This comprehensive perspective includes their capability of being media and digital literate. The teacher persuasively guides the students to ignore any fake news and or hoax. The WhatsApp group is only intended for the students to communicate each other and to the teachers. Some parents joining this group are only allowed to observe the online activities attended by their children. Irrelevant comments or postings are not welcomed. Teacher always supports the students to share only credible information and ignore irrelevant information, fake news or hoax. It implies the encouragement of getting and sharing no fake information in the WhatsApp group chats. Shortly, students are guided to be capable of improve their media and digital literacy. (Grenfell 2020)

\section{Social Compassion.}

Developing empathic communication \& collaboration

During observation, no inappropriate linguistic expressions can be found. The teacher always uses formal linguistic expression. It is also polite, either when the teacher communicate classically or individually. No offensive statements can take place in chats. He is becoming an ideal model of communication. This results in the pattern of students' communication during the online class. Students mostly use their 'best appropriate linguistic expression' to communicate each other. Undoubtfully, they start not only communication each other but also relating to each other. (ICAJE 2021)

This observation ends when students join the final examination. Concluding the research findings and discussions, none of the students in the class need to have a remedial class. On the next grade the habitus of managing good interpersonal communication, social compassion and better media and digital literacy continue to happen.

\section{CLOSURE}

It might have been possibly to state that based on the research, it can be concluded that sinergetic collaboration of some aspect as discussed in this research lead to the optimal academic performance, media and digital literacy and acquisition of the norms social compassion in distance learning. It requires both teachers and students competences to perform well in interpersonal perspective of communication and relation. It requires teachers' media and digital literacy. It is important because they are digital immigrants who are facing their counterparts of digital natives. It requires too, the educational philosophical capabilities of the teachers by mastering the education paradigms under which they are managing their students in educational corridors to humanize the younger generations.

Relating to digital natives, the biggest problem is that the digital immigrant teachers speak in an old version of pre-digital age and they are trying to teach those digital natives who speaks in new type of languages. Considering the digital natives as same as in the era of digital immigrants is a big mistake. Most of the assumption of digital immigrants about digital natives is no longer credible. Educators must be willing to try to teach either legacy or future content on relevant methods to digital natives and in the 'language' of digital natives.

Digital immigrants should not only adapt to digital natives' way of learning, but reconsidering their approach in teaching them. On the basis of lifelong learning, digital learning methods are attractive. To be more frank, digital immigrants should change the educational approach and or paradigms. Focusing, in teaching, on methodology, legacy content and future content into a teaching melting pot of education is necessary and 
critical. To be able to do so, self-improvements on either educational competences or being technological savvy by being media and digital literate individual is a must. Finally speaking, Integrating academic excellence and humanistic values though online learning is still possible to conduct during the Covid-19 pandemic.

To perfecting this research, it needs to call for further deeper research in the same areas especially in the context of future distance learning. It is critical so because the establishment and ongoing development of the digital is still massively happening.

\section{REFERENCES}

Undang Undang No 23 Th 2003

2012. Paradigma Pedagogi Reflektif. Mendampingi Peserta Didik Menjadi Cerdas dan Berkarakter. Edisi Revisi. Jogjakarta: Kanisius.

Tapscott, Don. (2008) Grown Up Digital. How the Net Generation is Changing Your World. USA: McGraw-Hill

DeVito, Joseph A. (2016) The Interpersonal Communication Book. 14th Ed. USA: Pearson

Driyarkara, N. 2006. Karya Lengkap Driyarkara. Esai-Esai Filsafat Pemikir yang Terlibat Penuh dalam Perjuangan Bangsanya. Jakarta: PT Gramedia Pustaka Utama, Kanisius, Kompas Penerbit Buku.

https://www.bps.go.id/publication/2021/

www.unicef.org

https://uopeople.edu

http://communicationtheory.org/

https://www.marcprensky.com/

http://scihi.org/communication-paul-watzlawick/

https://www.jesuits.global/ministries/education/icaje/

Sahid, Dadang Syarif Sihabudin. 2020. Isu dan Strategi Pembelajaran Daring 'Belajar dari Covid-19'. Seminar Online APTIKOM Riau, 2 Mei 2020. Accessed 2 May 2020

Filsafat Pendidikan Driyarkara, Esensi Pendidikan dan Penerapannya dalam Konteks New Normal. Webinar Strada, Sabtu, 23 Januari 2021, diakses 23 Januari 2021.

Maqbulin, Arjunina. 2021. Problem of Online Learning During Pandemic. https://bdksurabaya.e-journal.id/bdksurabaya/issue/view/10

Safrizal dkk. 2021. Difficulties of Implementing Online Learning in Kindergarten during Pandemic; Teacher's Perspective Review https://ejournal.undiksha.ac.id/index.php/JPP/article/view/34974/pdf

Hermanto, Yustinus Budi dan Veronika Agustini Srimulyani. 2021. The Challenges of Online Learning During the Covid-19 Pandemic. https://ejournal.undiksha.ac.id/index.php/JPP/

Grenfell, Jenny. 2020. Through the looking glass: teaching and learning in blended immersive multiuser virtual and real world environments. https://www.researchgate.net/publication/235662067

Stoerger, Sharon. 2020. The Digital Melting Pot. https://comminfo.rutgers.edu/stoergersharon 